\title{
Effects of surrounding crop and semi-natural vegetation on the plant diversity of paddy fields
}

\author{
Nur Rochmah Kumalasari ${ }^{1,2^{*}}$ and Erwin Bergmeier ${ }^{1}$
}

\begin{abstract}
Background: The ecosystems around, and plant composition in, paddy fields in Java are varied, owing to differences in climate, altitude, and traditional farming practice. This study examines the effects of different types of surrounding land use and vegetation on the plant diversity in paddy fields.

Methods: We studied three upland (400-850 $\mathrm{m}$ asl) and three lowland areas (10-50 $\mathrm{m}$ asl) in the island of Java, Indonesia. Samples of vegetation were taken in fields and bunds (partition between paddy field plots) in two rice cultivation seasons from October 2011 through to June 2012, including the peak of rice cultivation in Java between October and February. We used Analysis of Variance Matrix Unbalanced to analyze the effects of area, complexity, location, and season on plant composition. Tukey's Honestly Significant Difference (HSD) test was performed to determine significant differences between groups in the sample.

Results: We recorded 14 crop species and 221 non-cultivated plant species, of which 171 species occurred in paddy fields and 190 on bunds. Species numbers in upland areas were higher than in lowland areas. In fallows, twice as many species as in cultivated rice fields were found. The presence of semi-natural vegetation within short distance had no significant effect on plant species numbers in paddy fields. Multiple cropping and intercropping around paddy fields and on bunds had a marked effect on plant diversity.

Conclusions: Differences in plant species numbers and composition between lowland and upland areas are more pronounced than the effects of local environmental complexity. To enhance high and varied plant diversity on the field and landscape scale, traditional multiple and intercropping systems should be supported.
\end{abstract}

Keywords: Bund, Cultivation season, Fallow, Java, Landscape complexity, Monoculture, Multiple cropping, Rice field, Weeds

\section{Background}

Environmental factors and management are the most important general drivers of plant species richness, abundance, and composition in agroecosystems [1-4]. Weeds, defined here as non-cultivated plants of crop fields, may hamper land management and food production but support biological diversity, diversify food webs and potential food resources, and improve soil health $[5,6]$. Weed communities differ in relation to environmental and landscape structural heterogeneity [2,7], and

\footnotetext{
* Correspondence: nurrkumala@gmail.com

${ }^{1}$ Department of Vegetation \& Phytodiversity Analysis, Albrecht-von-Haller Institute of Plant Sciences, Georg-August University of Göttingen, D-37073 Göttingen, Germany

${ }^{2}$ Department of Nutrition and Feed Technology, Faculty of Animal Science, Bogor Agricultural University (IPB), Bogor, Indonesia
}

even the seed banks in arable lands are influenced by landscape complexity $[8,9]$.

The ecosystems around paddy fields in Java are varied, owing to differences in climate and altitude and because traditional farming varies across villages [10]. Available resources and the local natural environmental conditions, such as season, water availability, landscape, and natural vegetation, determine the type and complexity of land use. For instance, in the rainy season, water availability is increased both in irrigated and rain-fed paddy fields, a factor that is important for rice plant growth and weed management [11].

Javanese rice farmers commonly divide a year in three rain-dependent cultivation seasons. The prime cultivation (between the end of October till March) starts in the wet season, the second cultivation period is in the 
medium-wet season around April-July, and the third is the dry season between August and October [12]. The optimum cultivation date is indicated by the soil moisture level required for planting and in general by the water availability to be expected in the coming period [13]. Compared with 1961-1970, the length of the rainy season changed slightly and the number of wet months had a degressive trend in the period after 1991 [14], resulting in a shift in timing of rice planting and cultivation management.

To remain competitive and to provide food, feed, and industrial crops to satisfy the increasing demands of people, smallholder rice farmers in Java commonly practice intercropping or multiple cropping (polycultures). To increase their incomes, rice farmers cultivate two or more crops per year on the same land [15]. Intercropping and multiple cropping have a favorable effect on sustainable agriculture [16], as soil fertility is increased [17-19] and weed infestation prevented to some extent. Intercropping was found to influence the weed composition in adjacent fields and reduced weed densities by two-thirds [20,21]. Weed seed densities under crop rotation decreased by one-third in comparison to continuous cropping [22]. Owing to the ecology and phenology of plants, weed community composition and density are thus related to intercropping.

In this study, the effects of different types of surrounding vegetation on the plant diversity in paddy fields of smallholders in Java are examined. The objective was to understand whether the weeds in the paddy fields are influenced by customary multiple-crop systems nearby paddy fields, by the vegetation at their margins, and by surrounding semi-natural vegetation. The aim was to provide a scientific basis for developing an integrated weed management strategy for paddy fields respecting local agricultural traditions of food security and agroecosystem functioning.

We hypothesize, first, that weed species numbers and composition in paddy fields are lower than at their margins (bunds) and, second, that surrounding crops and semi-natural vegetation influence the weed diversity.

\section{Methods}

\section{Characteristics of study areas and data sampling}

We studied sites of $5 \times 5 \mathrm{~km}$ in six areas in the island of Java, Indonesia, i.e. Cugenang, Karanganyar, Malang, Karawang, Brebes, and Gresik. The first three are representative of upland rice cropping systems $(400-850 \mathrm{~m}$ asl). In the upland areas, the annual rainfall amounts to $3,100-4,600 \mathrm{~mm}$ and is concentrated in the period between September and May (Figure 1). The temperature ranges between $20^{\circ} \mathrm{C}$ and $27^{\circ} \mathrm{C}$, depending on altitude. The other three study sites are representative of lowland rice cropping systems $(10-50 \mathrm{~m}$ asl). The annual rainfall of $1,300-2,550 \mathrm{~mm}$ is mainly during the southwest monsoon between September and April in Gresik and Brebes and from December in Karawang. The temperature ranges from $26^{\circ} \mathrm{C}$ to $30^{\circ} \mathrm{C}$ (Figure 1 ).

The size of the terraces under cultivation varied depending on topography, contour, and ownership; but in flat areas, terraces were usually around $50 \times 100 \mathrm{~m}$. In upland areas of Central Java, terraces were between 56 and $176 \mathrm{~m}^{2}$ in size and shaped so as to descending to the river [23]. Bunds are linear structures dividing rice fields to control the water depth. Varying in style with the riverbed slope [24], they are at least $20 \mathrm{~cm}$ high and between 15 and $150 \mathrm{~cm}$ wide, with the shape depending on the paddy topography. The water depth is controlled and regulated by the spillway height (around $5 \mathrm{~cm}$ ) (Figure 2). In Indonesia, bunds are plowed in and rebuilt each season using the mud of the plow layer to make a boundary between paddy fields, to provide a footpath, and to control water level [25].

Paddy fields were classed as either cultivated or fallow. On the basis of our survey of the sites, we classed paddy fields, bunds, and landscapes as either simple or complex. We noted the distance from the sampled paddy field to the nearest semi-natural vegetation to identify 'complex' or 'simple' conditions of paddy fields (Table 1). 'Complex landscape' means farmland where rice has been planted together with other crops in short distance. 'Complex bund' is farmland where rice has been planted together with other crops or trees on the bunds. Further, we noted the bunds' width and plant cover. 'Simple' paddy fields, bunds, and landscapes are farmlands where rice has been planted without another crop in the fields, on terraces and/or bunds, and with no or distant seminatural vegetation around.

'Other crops' in this work are any arable or horticultural crop plants cultivated in spatial sequence and/or interplanted in the paddy fields or on bunds [26], such as corn, mungbean, soybean, chili, onion, etc. They form part of polyculture or multiple cropping systems that are commonly and extensively practiced by Indonesian farmers in the dry season. In 'semi-natural' vegetation, species composition and/or abundance has been altered through anthropogenic disturbances. While no clear natural analog may be known, they consist of a largely spontaneous and native set of plants shaped by ecological and phytogeographical processes (definition modified after Federal Geographic Data Committee [7]).

\section{Statistical analysis}

This analysis was conducted at the area level, by considering all weed species surveyed within each area. To reduce statistical noise, species present in only one plot in one area were omitted. 


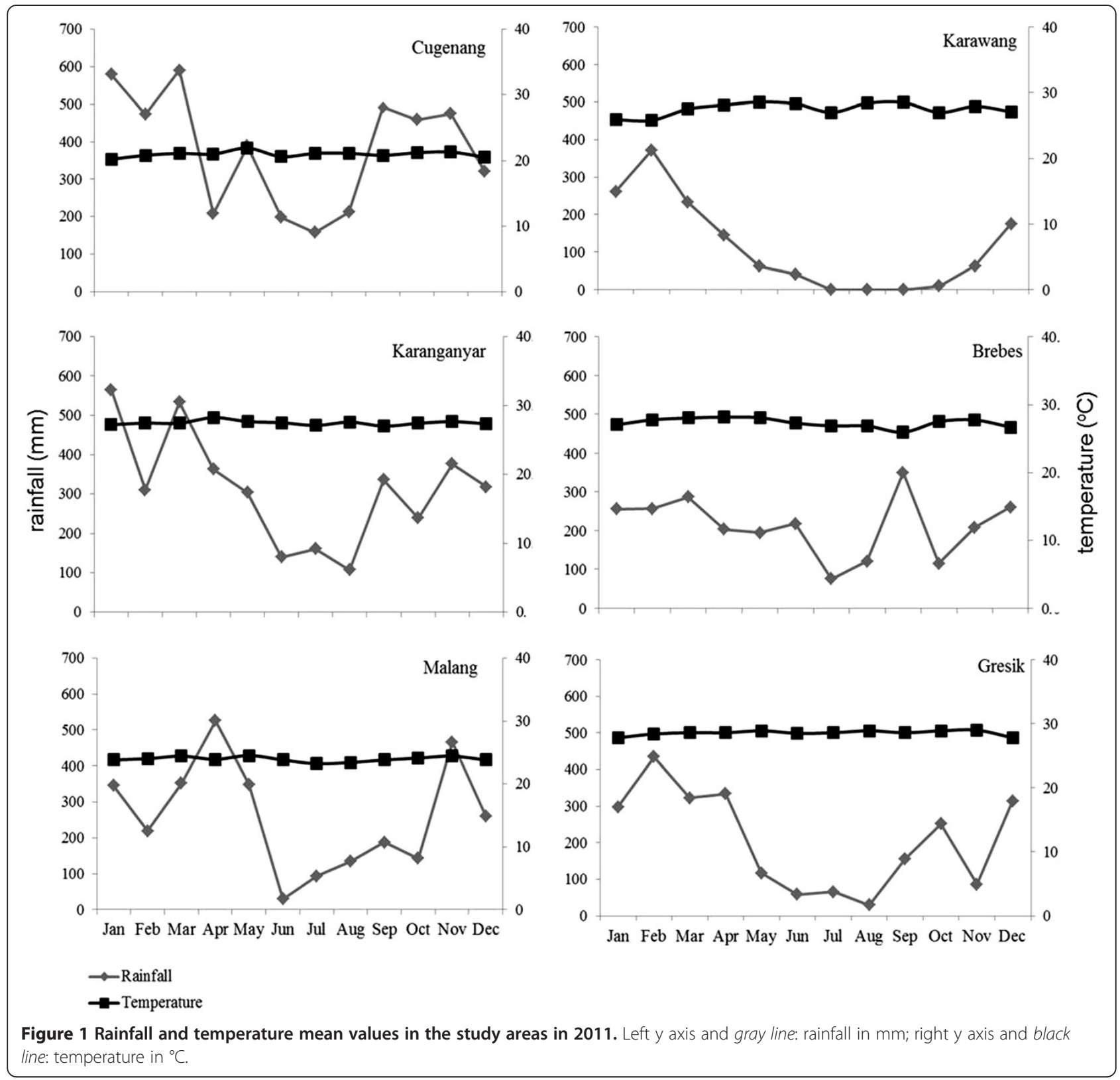

We used Analysis of Variance Matrix Unbalanced to analyze the effect of the sample sites, complexity, location, and season on weed composition using presence/absence data. We divided the sample plots in three categories, i.e. cultivated paddy fields, fallows, and bunds. We determined the complexity in terms of presence or absence of semi-natural vegetation and other crops surrounding the paddy fields (Table 1). The 'complexity' condition of fields and bunds was ranked $1=$ simple or $2=$ complex. Similarly, at the landscape level, monoculture and multiple cropping were distinguished. Cultivation seasons were 1 = October-December or 2 = May-June.

The effects of complexity, season, and area on rice weed diversity at the field level were analyzed for all weed species. The variables were log- or square-root transformed if necessary to meet the normality requirement for the residual. To determine the key factor(s) influencing weed diversity and quantitative interrelationships, backwards stepwise multiple regression analysis was applied using the criteria of probability of $p<0.05$ to accept and $p>0.1$ to remove the variable from the analysis. The analyses were performed in $\mathrm{R} \times 643.0 .2$ software (R Development Core Team, Vienna, 2013) using the 'Rcmdr' and 'library CAR' packages. Furthermore, Tukey's Honestly Significant Difference (HSD) test was performed to determine significant differences between groups in the sample. 


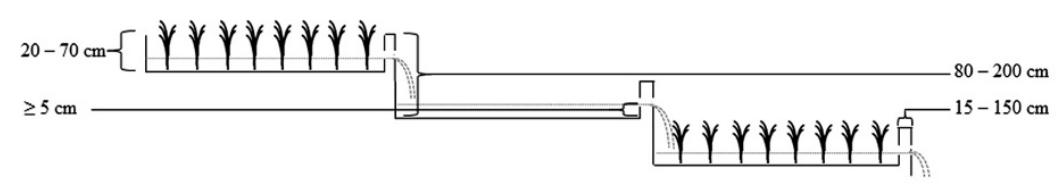

(a)

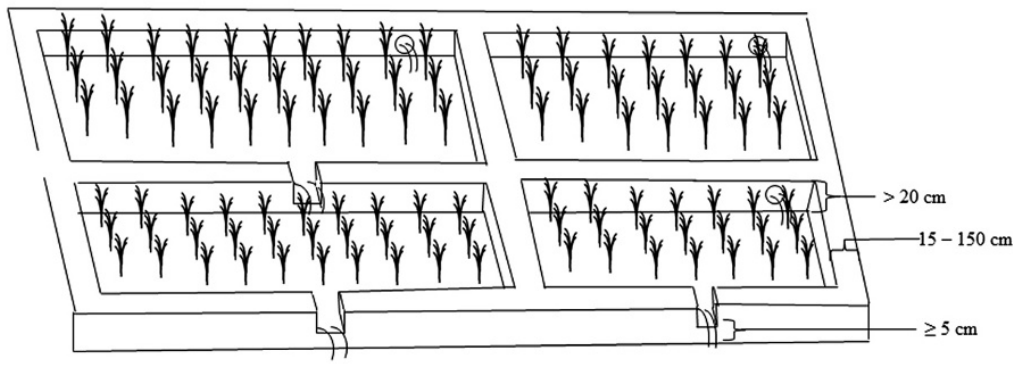

(b)

Figure 2 Scheme of bund, terrace, and field dimensions. Upland (a) and lowland (b) rice fields. Samples of vegetation were taken in a period from October 2011 through to June 2012, i.e. including two cultivation seasons October-December and May-June. The weed vegetation was surveyed in each of the six paddy field sites on a regular grid of sample plots. Each site comprised 33 plots of paddy fields, $20 \mathrm{~m}^{2}$ in size, and 33 plots of bunds, $10 \mathrm{~m}^{2}$ in size. Total vascular plant species composition was determined per plot.

\section{Results}

Characteristics and variation of the paddy field environment We mapped seven types of semi-natural vegetation, i.e. conservation forest, bamboo forest, community garden, basin, grassland, fallow, and artificial lake vegetation. In terraces, farmers planted horticultural plants, viz. cassava, mungbean, soybean, chili, tomato, onion, sugarcane, and corn. On cropped bunds, the farmers planted trees and grass for animal feed and own consumption, such as banana, coconut, guava, Sesbania grandiflora, Setaria spachelata var. splendida, and Pennisetum purpureum.

In each area, we found various environment types around paddy fields (Table 2). In Gresik, most farmers build a special large-sized bund of around $1.5 \mathrm{~m}$ height and 1-1.5 m width, meant to prevent water overflow in the rainy season, to maintain suitable water depth for small-scale fish farming, and to keep water until the dry season.

The start of cultivation time varied across Java (Table 3). In upland areas, the first rice cultivation started around October. In lowland areas, the beginning of cultivation depended

Table 1 Complexity criteria adopted for paddy fields, bunds, and paddy landscape sections

\begin{tabular}{|c|c|c|c|}
\hline & $\begin{array}{c}\text { Semi-natural } \\
\text { vegetation }<100 \mathrm{~m} \\
\text { apart }\end{array}$ & $\begin{array}{c}\text { Other crop than } \\
\text { rice }<100 \mathrm{~m} \\
\text { apart }\end{array}$ & $\begin{array}{c}\text { Other crop in } \\
\text { bund }<100 \mathrm{~m} \\
\text { apart }\end{array}$ \\
\hline $\begin{array}{l}\text { Complex } \\
\text { paddy } \\
\text { field }\end{array}$ & + & $+/-$ & $+/-$ \\
\hline $\begin{array}{l}\text { Complex } \\
\text { landscape }\end{array}$ & - & + & - \\
\hline $\begin{array}{l}\text { Complex } \\
\text { bund }\end{array}$ & - & - & + \\
\hline
\end{tabular}

on rainfall and water availability. Lowland farmers commonly cultivate rice in the first and second cultivation season. Some farmers in Karanganyar and Brebes cultivate horticultural plants in the dry (third) season when water is insufficient for rice cultivation. Farmers in Gresik raised fish in their rice fields between January and March at the peak of the rainy season and with water overflow from paddy fields.

\section{Plant diversity in paddy fields and bunds}

Overall, we recorded 14 crop species and 221 non-cultivated plant species (weeds), of which 171 species occurred in paddy fields and 190 on bunds. Only 116 species (52\%) were shared between paddy fields and bunds. Weed composition differed markedly between paddy fields and bunds (Tukey's HSD test: $t=-11.7925, \mathrm{df}=383.841, \quad p$ value $<2.2 \mathrm{e}-16)$. Mean weed species numbers in paddy fields were 9.5 , whereas on bunds species numbers were significantly higher $(18.4 ; p<0.05)$.

Plant species numbers differed much between cultivated fields, fallows, and bunds (Figure 3). In fallows, twice as many species as in cultivated rice fields were found. The highest species numbers occurred in the three upland areas while the lowland areas and particularly the district of Karawang had much lower weed species numbers. The presence of semi-natural vegetation within short distance had no significant effect on weed species numbers in paddy fields. Species numbers in 'complex' bunds and in multiple-crop landscapes were higher than in 'simple' bunds and in monoculture landscapes, respectively. Table 4 shows the results of the Analysis of Variance Matrix Unbalanced on the transformed data. Weed species numbers differed markedly between sample categories, areas, and seasons, as did the environment complexity categories of landscapes and bunds. 
Table 2 Environment types of paddy fields in each area

\begin{tabular}{|c|c|c|c|c|c|c|c|}
\hline & $n$ & $\begin{array}{l}\text { Cugenang } \\
33\end{array}$ & $\begin{array}{l}\text { Karawang } \\
33\end{array}$ & $\begin{array}{l}\text { Karanganyar } \\
33\end{array}$ & $\begin{array}{l}\text { Brebes } \\
33\end{array}$ & $\begin{array}{l}\text { Malang } \\
33\end{array}$ & $\begin{array}{l}\text { Gresik } \\
33\end{array}$ \\
\hline \multicolumn{8}{|l|}{ Type of field (\%) } \\
\hline Simple & 94 & 51.5 & 66.7 & 33.3 & 51.5 & 42.4 & 39.4 \\
\hline Complex & 104 & 48.5 & 33.3 & 66.7 & 48.5 & 57.6 & 60.6 \\
\hline Mean distance of complex field to semi-natural vegetation (m) & & $46.3 \pm 33.3$ & $37.3 \pm 22.3$ & $39.1 \pm 29.6$ & $61.3 \pm 38.4$ & $40.3 \pm 32.0$ & $48.6 \pm 37.2$ \\
\hline \multicolumn{8}{|l|}{ Type of landscape (\%) } \\
\hline Monoculture & 73 & 18.2 & 81.8 & 36.0 & 33.3 & 36.0 & 15.2 \\
\hline Multiple crop & 125 & 81.8 & 18.2 & 64.0 & 66.7 & 64.0 & 84.8 \\
\hline Multiple crop: mean distance to other crops (m) & & $6.2 \pm 9.3$ & $5.7 \pm 4.4$ & $14.9 \pm 11.1$ & $19.1 \pm 20.5$ & $7.9 \pm 8.0$ & $4.2 \pm 5.8$ \\
\hline \multicolumn{8}{|l|}{ Type of bund (\%) } \\
\hline Simple & 160 & 80.0 & 100 & 87.9 & 100 & 30.3 & 87.9 \\
\hline Complex & 38 & 20.0 & 0 & 12.1 & 0 & 69.7 & 12.1 \\
\hline Mean bund width $(\mathrm{cm})$ & & $74.5 \pm 32.1$ & $48.8 \pm 22.6$ & $48.6 \pm 24.3$ & $41.1 \pm 10.1$ & $53.3 \pm 24.2$ & $98.0 \pm 62.8$ \\
\hline Bund vegetation cover (\%) & & $64.8 \pm 27.0$ & $26.0 \pm 24.4$ & $59.7 \pm 29.4$ & $32.4 \pm 27.8$ & $61.4 \pm 29.8$ & $65.5 \pm 27.9$ \\
\hline
\end{tabular}

Inspection of all environmental effects showed that weed species numbers were significantly higher in fallow fields with complex landscape and bund, in Cugenang or Malang in the first season (Table 5). The total species number in bunds (190) was higher than in fallow fields (142) and cultivated fields (133).

At the landscape level, multiple-crop farming systems around paddy fields resulted in increased species numbers by about $10 \%$ in the paddy fields, compared to monoculture systems. Compared to simple bunds, crop cultivation on bunds had a significant effect, with about $25 \%$ higher species numbers in paddy fields (Table 5).

\section{Discussion}

\section{Plant diversity in rice fields}

The composition, total mass of plants in a stand, and population of rice weeds vary greatly under different habitat conditions and land use. In traditional agricultural systems such as in Java, farmers commonly use weeds as fodder resource, either grazed directly by ruminants or else cut, harvested, and given as fresh feed to cattle [27]. Moreover, many rice field plants are useful to farmers and villagers as medicinal or food resource, or for cultural and religious ceremonies [28,29]. Integrated weed management must therefore be biodiversity-friendly, attempting to sustain weed species of value for farmers and agroecosystems. The use of weeds as in traditional rice farming systems is moreover beneficial in order to overcome problems of pollution through herbicides. Habitat compartmentation, niches, overall diversity, and its regional variation in paddy field landscapes are as yet insufficiently studied. In particular, the effects of land use and landscape patterning on biodiversity and ecosystem functioning deserve to be further explored. In our study, we examined therefore which land use and environmental factors influence the plant diversity of rice fields and its local variation in Java.

Our results showed that the weed species numbers on the bunds were significantly different from those in cultivated paddy fields. The presence of crops on bunds was correlated with an increase in weed species numbers in paddy fields, supporting Palmer and Maurer [30] who found that high diversity in multiple-crop systems promoted the number of weed species.

Javanese farmers commonly let weeds grow or cultivate other crops on the bunds. Different crops use different soil resources and have different canopy structure, thereby

Table 3 Seasonality of paddy field cultivation in the Javanese study areas from October through September

\begin{tabular}{|c|c|c|c|c|c|c|c|c|c|c|c|c|}
\hline Cultivation season (month) & 10 & 11 & 12 & 1 & 2 & 3 & 4 & 5 & 6 & 7 & 8 & 9 \\
\hline Cugenang & $r$ & $r$ & $r$ & $r / f$ & $r$ & $r$ & $r$ & $r / f$ & $r$ & $r$ & $r$ & $r / f$ \\
\hline Malang & $r$ & $r$ & $r$ & $r / f$ & $r$ & r & $r$ & $r / f$ & $r$ & $r$ & $r$ & $r / f$ \\
\hline Karanganyar & $r$ & $r$ & r & $r / f$ & $r$ & r & $r$ & $r / f$ & h & h & h & $\mathrm{h}$ \\
\hline Gresik & $r$ & $r$ & $r$ & s & $\mathrm{s}$ & $\mathrm{s}$ & $r$ & $r$ & $r$ & $r / f$ & f & f \\
\hline Brebes & $h / r$ & $r$ & r & $r$ & f & $r$ & $r$ & $r$ & h & h & h & $\mathrm{h}$ \\
\hline Karawang & $f$ & $f / r$ & $r$ & $r$ & $r$ & $r / f$ & $f / r$ & $r$ & $r$ & $r$ & $r / f$ & f \\
\hline
\end{tabular}

$r$, rice plants cultivated; $h$, horticultural plants cultivated; $f$, fallow; $s$, small fish farming; $r / f, f / r$, or $h / r$ transitional time (rice plants cultivated to fallow; fallow to rice plants cultivated, or horticultural plants cultivated to rice plants cultivated). 

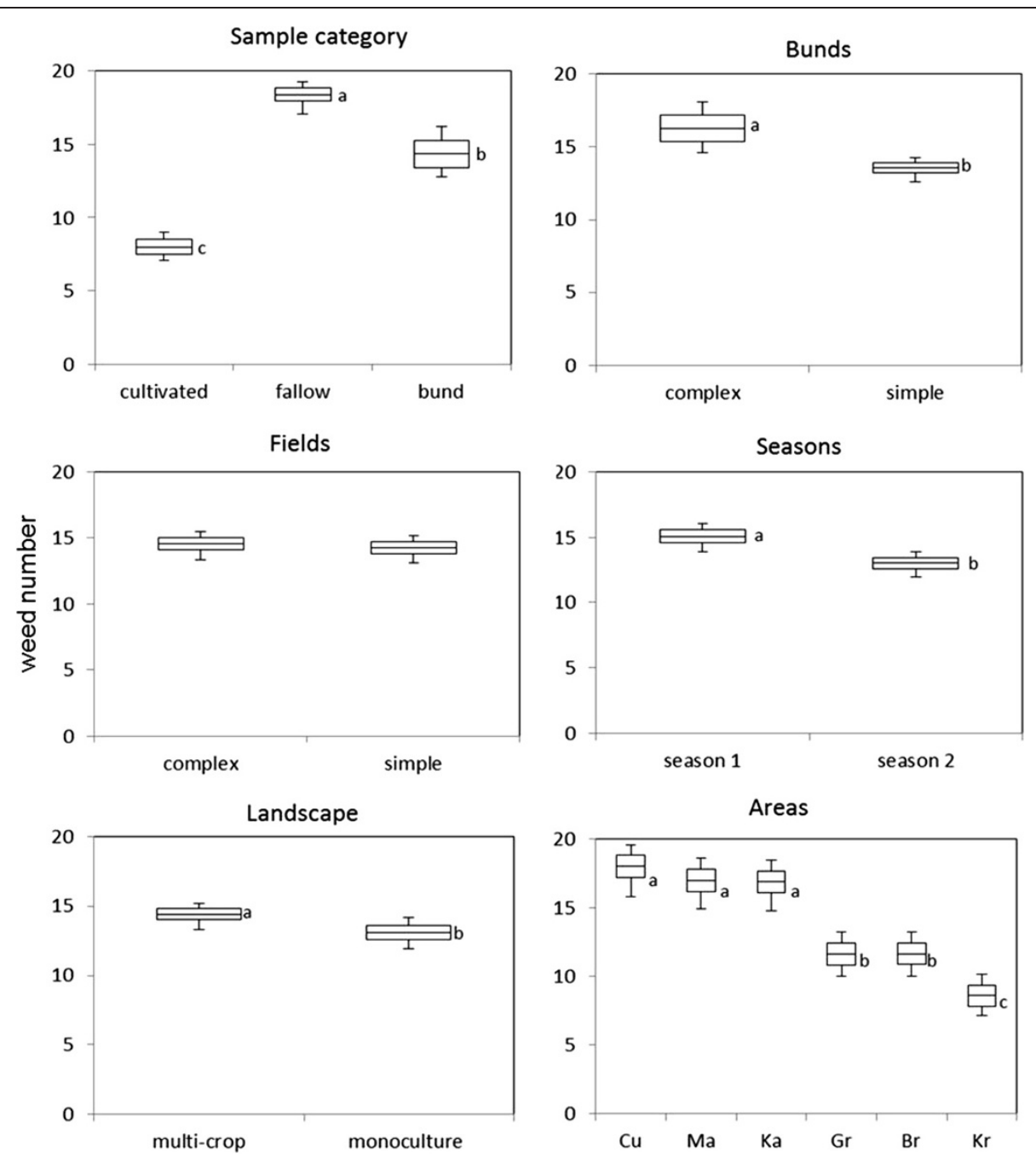

Figure 3 Mean $( \pm \mathrm{SE})$ weed species numbers of sample categories; field, landscape, and bund types; areas; and seasons. $\mathrm{CU}=\mathrm{Cugenang}$, $\mathrm{Ma}=$ Malang, $\mathrm{Ka}=$ Karanganyar, $\mathrm{Br}=$ Brebes, $\mathrm{Kr}=$ Karawang, $\mathrm{Gr}=$ Gresik.

creating microhabitat conditions that may further increase the number of weed species and enhance the differences between weed communities in fields and on bunds. Subudhi et al. [23] reported that the structure of bunds affected rice yield as well as soil and moisture content. Organic matter, $\mathrm{pH}$ level, and nutrients $(\mathrm{N}, \mathrm{P}, \mathrm{K}, \mathrm{Ca}$, and
$\mathrm{Mg}$ ) were found higher in paddy fields with trees on the bunds, especially leguminous trees [19].

As a result of weed control, overall diversity of weeds in cultivated plots was less than in the fallows and on the bunds. The higher number of weeds in fallows suggests that the soil seed bank in paddy fields is significant

Table 4 Testing for differences in the number of weed species by using Analysis of Variance Matrix Unbalanced

\begin{tabular}{|c|c|c|c|c|c|c|}
\hline & Df & Sum Sq & Mean Sq & $F$ value & $\operatorname{Pr}(>F)$ & \\
\hline Sample category & 2 & $9,299.7$ & $4,649.9$ & 133.4537 & $<2.2 \mathrm{e}-16$ & $* * *$ \\
\hline Field (simple vs. complex) & 1 & 3.3 & 3.3 & 0.0794 & 0.778330 & \\
\hline Landscape (monoculture vs. multicrops) & 1 & 216.4 & 216.4 & 5.2796 & 0.022114 & * \\
\hline Bund (simple vs. complex) & 1 & 316.5 & 316.5 & 7.7232 & 0.005720 & $* *$ \\
\hline Area & 5 & $4,125.9$ & 825.2 & 20.1338 & $<2.2 \mathrm{e}-16$ & $* * *$ \\
\hline Season & 1 & 352.9 & 352.9 & 8.6111 & 0.003542 & $* * *$ \\
\hline
\end{tabular}

Significance codes: ${ }^{*} 0.01 ;{ }^{* *} 0.001 ;{ }^{* * *} 0$. 
Table 5 Tukey's HSD test on the mean species numbers in different environments

\begin{tabular}{lcc}
\hline Treatments & Mean species numbers & SE \\
\hline Sample category & 7.9 & \\
Cultivated & 18.4 & $\pm 0.5^{\mathrm{c}}$ \\
Fallow & 14.4 & $\pm 0.5^{\mathrm{a}}$ \\
Bund & & $\pm 0.9^{\mathrm{b}}$ \\
Landscape & 14.4 & \\
Multiple crop & 13.1 & $\pm 0.4^{\mathrm{a}}$ \\
Monoculture & & $\pm 0.5^{\mathrm{b}}$ \\
Bund complexity & 16.3 & \\
Complex & 13.6 & $\pm 0.9^{\mathrm{a}}$ \\
Simple & & $\pm 0.4^{\mathrm{b}}$ \\
Area & 17.9 & \\
Cugenang & 16.9 & $\pm 0.8^{\mathrm{a}}$ \\
Malang & 16.9 & $\pm 0.8^{\mathrm{a}}$ \\
Karanganyar & 11.6 & $\pm 0.8^{\mathrm{a}}$ \\
Gresik & 11.6 & $\pm 0.8^{\mathrm{b}}$ \\
Brebes & 8.6 & $\pm 0.8^{\mathrm{b}}$ \\
Karawang & & $\pm 0.8^{\mathrm{c}}$ \\
Season & 15.1 & $\pm 0.5^{\mathrm{a}}$ \\
Season 1 & 13.0 & $\pm 0.4^{\mathrm{b}}$ \\
Season 2 &
\end{tabular}

[31] and triggers the germination of plants adapted to the relatively dry conditions of fallows. Local differences in weed composition among paddy fields are therefore chiefly due to season and cultivation stage.

The effects of rice cultivation on weed diversity vary with the production methods applied, whether fields are managed organically or with agrochemicals, and which irrigation and planting systems are used [1]. In a review, Navas [16] concluded that there are two factor groups determining weed diversity, i.e. local environmental conditions (climate, soil, land use history) and crop/treatment related factors (current or preceding crop type, land drainage, fertilization, tillage, and herbicide application). Irrigation and its frequency are to be added here [32]. We found that cultivated paddy fields in the rainy season serve as a suitable habitat for many hydrophilous plants (Kumalasari, unpublished). The hydrophilous plants have lifecycle along rice cultivation and most of them ended after harvest. This condition is related with water availability that depends on different number of rainfall in each season, water management, and rice plant stage.

The effect of complexity of fields, bunds, and landscapes Contrary to our expectations, weed species numbers in paddy fields were unrelated to the semi-natural vegetation nearby. In contrast, in temperate arable landscapes, weed species diversity was influenced by landscape complexity [21]. There may be an effect though, not studied by us, between paddy weed diversity and semi-natural vegetation, acting at shorter distances. In any case, the influence of adjacent agricultural management, in particular of other crops nearby, on plant species numbers seems to be more pronounced than that of other vegetation formations [33], which may be explained by the fact that paddies and semi-natural formations have but few species in common.

Positive effects of intercropping on organic carbon, soil nitrogen, some micronutrients [18], total soil nutrients and thus, on nutrient uptake [17] are well-known. As those nutrients are essential for plant growth in general, both crops and weeds profit from multiple-crop systems [34]. In the present study, intercropping around paddy fields and on bunds had a considerable effect on weed species numbers (Table 5). Also, other researchers reported on the effects of agricultural seasonality, such as fallow management [35] and intercropping [36], on weed species in tropical fields.

The intervening time between harvest and the next rice cultivation in Java varies; meanwhile, the land typically lies fallow. The duration of the fallow period is determined by rainfall and may be as short as three weeks in the upland areas of Java and up to 16 weeks in the lowlands. Our research showed that season has an effect on species numbers, thus supporting [37] in that there was more weed growth in the dry season than in the wet season (but see [38]).

\section{Conclusions}

The comparison of paddy weed species numbers in different areas and environments showed that sample category, area, and season contribute most to overall local species richness. Our study underlines moreover the significance of local management and landscape patterning for plant species diversity. Whether landscapes and bunds are 'complex' or 'simple' has an effect on species numbers in paddy fields. Altogether, differences in weed species numbers and composition between areas are more pronounced than the effects of local environmental complexity. Thus, to support species diversity in lowland paddy fields, intercropping of horticultural plants should be maintained. In the upland areas, multiple cropping and the presence of fruit trees or crops on the bunds were positively related to plant species diversity and are thus recommended for an integrated agricultural management and to support agroecosystem functioning for the local smallholder communities. It is further essential to maintain, pass on, and teach the traditional knowledge of plant life in paddy fields and the local farming practice to preserve the plant diversity and to perpetuate its use. 


\section{Competing interests}

The authors declare that they have no competing interests.

\section{Authors' contributions}

NRK conceived of the study, carried out the field work, performed the statistical analysis, and drafted the manuscript. EB coordinated the study, contributed to the design, and helped to draft the manuscript. Both authors read and approved the final manuscript.

\section{Acknowledgements}

This work was supported through a scholarship from Erasmus Mundus Experts Asia (mobility program) and a PhD grant from BIOTROP (2012). We would like to thank Dr. Sri S. Tjitrosoedirdjo for invaluable support of the field work and laboratory research. We are grateful to Prof. Em. Soekisman Tjitrosemito and Prof. Luki Abdullah for their substantial contributions in designing the field work. Many thanks are also due to Adnan who assisted the data analysis.

Received: 16 April 2014 Accepted: 25 September 2014 Published: 21 October 2014

\section{References}

1. Donald PF: Issues in international conservation: Biodiversity impacts of some agricultural commodity production systems. Consen Biol 2004, 18:17-37.

2. Dornelas M, Moonen AC, Magurran AE, Bàrberi P: Species abundance distributions reveal environmental heterogeneity in modified landscapes. J Appl Ecol 2009, 46:666-672.

3. Espinosa-García FJ, Villaseñor $\mathrm{L}$, Vibrans $\mathrm{H}$ : The rich generally get richer, but there are exceptions: Correlations between species richness of native plant species and alien weeds in Mexico. Divers Distrib 2004, 10:399-407.

4. Otto S, Vasileiadis VP, Masin R, Zanin G: Evaluating weed diversity with indices of varying complexity in north-eastern Italy. Weed Res 2012, 52:373-382.

5. Marshall EJP, Brown VK, Boatman ND, Lutman PJW, Squire GR, Ward LK: The role of weeds in supporting biological diversity within crop fields. Weed Res 2003, 43:77-89.

6. Way MJ, Heong KL: The role of biodiversity in the dynamics and management of insect pests of tropical irrigated rice-a review. Bull Entomol Res 1994, 84:567-587.

7. FGDC: National Vegetation Classification Standard Version 2. FGDC-STD-0052008. Reston, Virginia, USA: Vegetation Subcommittee, Federal Geographic Data Committee, FGDC Secretariat, U.S. Geological Survey; 2008.

8. José-Maria L, Sans FX: Weed seedbanks in arable fields: effects of management practices and surrounding landscape. Weed Res 2011, 51:631-640.

9. Roschewitz I, Gabriel D, Tscharntke T, Thies C: The effects of landscape complexity on arable weed species diversity in organic and conventional farming. J Appl Ecol 2005, 42:873-882.

10. Sukristiyonubowo $S$ : Nutrient balances in terraced paddy fields under traditional irrigation in Indonesia. Gent: Gent University, Applied Analytical and Physical Chemistry; 2007. http://buck.ugent.be/fulltxt/RUG01/001/215/ 679/RUG01-001215679_2010_0001_AC.pdf.

11. Hoque MZ: Cropping systems in Asia: On-Farm Research and Management Los Baños (Philippines): International Rice Research Institute (IRRI); 1984.

12. Sumarno: Periodisasi Musim Tanam Padi sebagai Landasan Manajemen Produksi Beras Nasional. (periodization of rice cultivation season as a base of national production management). [http://203.176.181.70/bppi/lengkap/ st080206-1.pdf]

13. Tazhibayeva K, Townsend RM: The Impact of Climate Change on Rice Production: heterogeneity and uncertainty. [http://www.robertmtownsend.net/sites/ default/files/files/papers/working_papers/ImpactofClimateChangeonRiceYields Dec2012.pdf]

14. Pramudia A: Musim Hujan di Sentra Produksi Padi sudah Berubah (rainy season has changed in rice production centers). [http://203.176.181.70/bppi/ lengkap/kl060903.pdf]

15. Godoy R, Bennett CPA: The economics of monocropping and intercropping by smallholders: The case of coconuts in Indonesia. Hum Ecol 1991, 19:83-97.

16. Navas ML: Trait-based approaches to unravelling the assembly of weed communities and their impact on agro-ecosystem functioning. Weed Res 2012, 52:479-488.
17. Mohammaddoust-e-Chamanabad HR, Asghari A, Tulikov AM: The effects of weed-crop competition on nutrient uptake as affected by crop rotation and fertilizers. Pak J Biol Sci 2007, 10:4128-4131.

18. Prasad B, Umar SM: Effect of rice based six multiple cropping sequences under two cycles of crop rotations on yield and fertility status of soil. Plant Soil 1990, 127:251-258.

19. Sae-Lee S, Vityakon P, Prachaiyo B: Effects of trees on paddy bund on soil fertility and rice growth in Northern Thailand. Agroforestry 1992, 18:213-223

20. Gomez P, Gurevitch J: Weed community responses in a corn-soybean intercrop. App/ Veg Sci 1998, 1:281-288.

21. Rahnavard A, Ashrafi ZY, Alizade HM, Sadeghi S: Studies on the effect of fertilizer application and crop rotation on the weed infested fields in Iran. J Agric Technol 2009, 5:41-50.

22. Cardina J, Herms CP, Doohan DJ: Crop rotation and tillage system effects on weed seedbanks. Weed Sci 2002, 50:448-460.

23. Subudhi CR, Behera B, Samantary SK: Field bund structures for production of rice in North Eastern Ghats of Orissa, India. Res J Agric Sci 2010, 1:475-476.

24. Hoshikawa K, Kobayashi S: Study on structure and function of an earthen bund irrigation system in Northeast Thailand. Paddy Water Environ 2003, 1:165-171.

25. Walker SH, Rushton KR: Water losses through the bunds of irrigated rice fields interpreted through an analogue model. Agric Water Manag 1986, 11:59-73.

26. Gallaher RN: Multiple Cropping Systems. [http://www.eolss.net/samplechapters/c10/E5-15-02-04.pdf]

27. Kosaka Y, Takeda S, Sithirajvongsa S, Xaydala K: Plant diversity in paddy fields in relation to agricultural practices in Savannakhet province. Laos Econ Botany 2006, 60:49

28. Edirisinghe JP, Bambaradeniya CNB: Rice fields: an ecosystem rich in biodiversity. J Natl Sci Found Sri Lanka 2006, 34:57-59.

29. Kumalasari NR, Abdullah L, Bergmeier E: Nutrient assessment of paddy weeds as ruminant feed in Java. Livest Res Rural Dev 2014, 26:59. [http://www.lrrd.org//rrd26/4/kuma26059.html]

30. Palmer MW, Maurer TA: Does diversity beget diversity? A case study of crops and weeds. J Veg Sci 1997, 8:235-240.

31. De Rouw A, Casagrande M, Phaynaxay K, Soulileuth B, Saito K: Soil seedbanks in slash-and-burn rice fields of northern Laos. Weed Res 2013, 54:26-37.

32. Li RH, Qiang S: Composition of floating weed seeds in lowland rice fields in China and the effects of irrigation frequency and previous crops. Weed Res 2009, 49:417-427.

33. Gaba S, Chauvel B, Dessaint F, Bretagnolle V, Petit S: Weed species richness in winter wheat increases with landscape heterogeneity. Agric Ecosyst Environ 2010, 138:318-323.

34. Newton AC, Begg GS, Swanston JS: Deployment of diversity for enhanced crop function. Ann Appl Biol 2009, 154:309-322.

35. Awanyo L: Dealing with weedy problems in agriculture: the role of three agricultural land use management practices in the forest-savanna ecological zone of Ghana. Area 2008, 40:446-458.

36. Akobundu IO, Ekeleme F, Chikoye D: Influence of fallow management systems and frequency of cropping on weed growth and crop yield. Weed Res 1999, 39:241-256.

37. Chauhan BS, Johnson DE: Row spacing and weed control timing affect yield of aerobic rice. Field Crop Res 2011, 121:226-231.

38. Saito K, Azoma K, Rodenburg J: Plant characteristics associated with weed competitiveness of rice under upland and lowland conditions in West Africa. Field Crop Res 2010, 116:308-317.

doi:10.1186/2048-7010-3-15

Cite this article as: Kumalasari and Bergmeier: Effects of surrounding crop and semi-natural vegetation on the plant diversity of paddy fields. Agriculture \& Food Security 2014 3:15. 